\title{
THE EFFECT of GA3 AND SALINITY on GROWTH of ROSELLE (Hibiscus sabdariffa L.)
}

\author{
Aisar Novita ${ }^{*}$, Mohammad Basyuni ${ }^{2}$, Abdul Rahman Cemda ${ }^{3}$, Silvia Nora ${ }^{4}$, Merlyn \\ Mariana $^{4}$ \\ ${ }^{1 *}$ Departments of Agrotechnology, Faculty of Agriculture, \\ University of Muhammadiyah Sumatera Utara, Indonesia \\ ${ }^{2}$ Departments of Forestry, Faculty of Forestry, \\ Universitas Sumatera Utara, Indonesia \\ ${ }^{3}$ Departments of Agribussiness, Faculty of Agriculture, \\ University of Muhammadiyah Sumatera Utara, Indonesia \\ ${ }^{4}$ Politeknik Pembangunan Pertanian, Medan \\ *Corresponding author: aisarnovita@umsu.ac.id
}

\begin{abstract}
In order to alleviate the deleterious effects of salinity, different types of phytohormones have been used. Among them, $\mathrm{GA}_{3}$ has been the main focus of some plant scientists. This study aimed to evaluate the effect of gibberellic acid and salinity on growth and production of roselle (Hibiscus sabdariffa L). This research was conducted in a greenhouse of Agriculture Faculty, University of Sumatera Utara, Medan. The study used utterly randomized design with two factors. The first factor was gibberellic acids. They were gibberellic acid $\left(5 \mathrm{mg} \mathrm{L}^{-1}\right)$ and no gibberellic acid. The second factor was salinity. They were $0 \mathrm{dsm}^{-1}$ and 4-5 $\mathrm{dsm}^{-1}$. The interaction between gibberellic acid and salinity acid indicated a significant effect on the percentage of germination, chlorophyll $\mathrm{a}$ and $\mathrm{b}$ and beta-carotene. The application of giberellic acid helped in the tolerance of plants to salinity. Thus, application of $\mathrm{GA}_{3}$ become essential to improve overall productivity in salinity.
\end{abstract}

Keywords: salinity, gibberellic acid, Hibiscus sabdariffa.

\section{INTRODUCTION}

The conversion of agricultural land to residential and industrial areas has resulted in a reduction in agricultural land. This causes agricultural development to be directed at marginal lands such as saline soils. Saline soil is soil that contains a certain amount of neutral dissolved salt which adversely affects plant growth and production (Kusmiyati et al., 2014).
Rosella flower (Hibiscus sabdariffa L.) contains compounds that have antioxidant activity, so they can ward off free radicals. The usefulness value of roselle is very wide for both food and health, so that the potential for roselle diversification is quite large. The important content contained in rosella flower petals is an anthocyanin pigment which acts as an antioxidant (Nasifa and Husni, 2018). 
Growth regulators are non-nutritional organic compounds which in low concentrations can promote, inhibit or qualitatively change plant growth and development. One of the growth regulators that is often used is gibberellin $\left(\mathrm{GA}_{3}\right)$ which plays a role in influencing various physiological processes in plants (Maharani et al., 2018). According to Yasmin (2014), the application of the $\mathrm{GA}_{3}$ concentration given is able to stimulate plant growth by increasing plant height and leaf area. Giving $\mathrm{GA}_{3}$ was influenced by the concentration given, the concentration of $\mathrm{GA}_{3}$ needed by each type of plant was different. Giving the right concentration of $\mathrm{GA}_{3}$ can increase plant growth.

The application of $\mathrm{GA}_{3}$ reduced the inhibitory effect of $\mathrm{NaCl}$ on growth attributes and photosynthetic pigments in Hibiscus sabdariffaby inducing the enzyme activity and enhancing RWC, and thus $\mathrm{GA}_{3}$ helped in the tolerance of plants to salt stress (Ali et al., 2011). Therefore, research is needed to evaluate the effect of gibberellic acid and salinity on growth of roselle (Hibiscus sabdariffa $\mathrm{L}$ ).

\section{MATERIALS AND METHODS}

In order to study the effects of gibberellic acid and salinity on growth and production of roselle (Hibiscus sabdariffa L.) an experiment was conducted in a greenhouse of Agriculture Faculty, University of
Sumatera Utara, Medan. The research used a completely randomized design with two factors. The first factor was giberellic acids were gibberellic acid $\left(5 \mathrm{mg} \mathrm{L}^{-1}\right)$ and no gibberellic acid. The second factor was salinity were $0 \mathrm{dsm}^{-1}$ and $4 \mathrm{dSm}^{-1}$. If the effect ofdifferent treatments on the real variance, then tested further by Duncan's multiple range test.

Land preparation. Land located in the greenhouse area cleaned. Size of $10 \mathrm{~kg}$ polybags filled with top soil.

Seed preparation. The seeds were used in this research comes from Darmaga, Bogor, Jawa Barat. The varieties used was sabdariffa. The seeds were disinfected by alcohol $70 \%$ (for 10 seconds), sodium hypochlorite $10 \%$ (for 60 seconds) and benomyl 2:1000 (for one minute) Afterward, the seeds were rinsed with distilled water twice.

Gibberellic acid treatment. Seeds were soaked in $500 \mathrm{ml}$ of distilled water for 12 hours (no $\mathrm{GA}_{3}$ ), and the seeds were immersed in $500 \mathrm{ml}$ of a solution of $\mathrm{GA}_{3}$ for 12 hours and then redried to original weight with forced air under shade.

Salinity treatment. To apply the salinity treatment, the salty soil was taken from the Kecamatan Percut Sei Tuan, which was measured for its salinity using a DHL meter at a salinity level of $4 \mathrm{dSm}-1$. 
Measurements were made by taking saline soil samples, then drying them in the sun, then the saline soil weighed 10 grams per sample. Then put the soil sample into a beaker glass and add distilled water to $100 \mathrm{ml}$. then measured the salinity level using a DHL meter.

Planting. The seeds were germinated directly on the polybag according to each treatment.

\section{Parameters observed:}

Percentage of Germination. Germination percentage was calculated up to 1 WAP. Germination (DB) was calculated based onthe percentage of normal seedling compared to the number of seeds that germinated.

Germination percentage $=$ Number of seeds germinating per polybag The number of seeds planted per polybag

Chlorophylla and Chlorophyll b. Analysis of chlorophyll $\mathrm{a}$ and chlorophyll $\mathrm{b}$ was conducted in Laboratorium Central, Faculty of Agriculture, University of Sumatra Utara, Medan.

Beta-carotene Content. Analysis of betacarotene content performed at the Laboratorium Pangan, Agriculture Faculty, University of Sumatra Utara, Medan.

\section{RESULTS AND DISCUSSION}

Gibberellin and salinity stress conditions showed a significant effect on the growth and production variables of roselle such as the percentage of germination, chlorophyll a and b, beta-carotene (Table 1). Gibberellin markedly better impact on salt stress.

Gibberellic acid $\left(5 \mathrm{mg} \mathrm{L}^{-1}\right)$ under salt stress on roselle maintain germination success although chlorophyll a and $\mathrm{b}$ decreased and was not formed flowers (generative phase) to be harvested. This context is correlated to generative step because gibberellin given during seed soaking focused on sustaining the germination success, so do not increase levels of chlorophyll $a$ and $b$.

In this study the majority of the roselle are getting treatment salinity stress thus lowering the average thick cuticle, but when viewed from the flats of plants that survived produced an increase in the thickest of the thick cuticle contained in roselle that is subjected to salinity stress. The application of $\mathrm{GA}_{3}$ reduced the inhibitory effect of $\mathrm{NaCl}$ on growth attributes and photosynthetic pigments in Hibiscus sabdariffa by inducing the enzyme activity and enhancing RWC, and thus $\mathrm{GA}_{3}$ helped in the tolerance of plants to salt stress. Ali et al. (2011), the application of $\mathrm{GA}_{3}$ reduced the inhibitory effect of $\mathrm{NaCl}$ on growth attributes and photosynthetic pigments by inducing the enzymes CA activity and enhancing RWC. Therefore, it is suggested that $\mathrm{GA}_{3}$ might help in the tolerance of plants to salt stress. Novita et al., (2017), reported that Salinity not only affects leaf morphology and transpiration rate but also leads to 
reduction of total chlorophyll content as the salt concentration increases. All the growing tissues are potential sites for $\mathrm{GA}_{3}$ biosithesis. The developing fruit and seeds are the $\mathrm{GA}_{3}$ biosynthetic pathway. Moosavi et al., (2013) reported that salinity stress had a negative impact on germination rate, germination percentage, long sprouts, shoot length and roselle seed viability index (Hibiscus sabdariffa). Overall, salinity through increased osmotic pressure leads to a reduction in water uptake and metabolic and physiological processes will come under its influence. So that it causes delays in germination by increasing seed germination. Gibberellins are a group of phytohormones associated with dormancy and shedding of leaves (senescnese). The phytohormone Giberellin $\mathrm{GA}_{3}$ is a hormone that accelerates seed germination, shoots, stem elongation, leaf growth, stimulates flowering, fruit development, affects root growth and differentiation (Campbell, 2005).

Table 1. Average of Chlorophyll a, Chlorophyll b, Beta-carotene, Percentage of Germination and Beta-carotene on Interaction of Gibberellic Acid and Salinity Stress.

\begin{tabular}{ccccc}
\hline Treatment & Chlorophyll a & $\begin{array}{c}\text { Chlorophyll } \\
\text { b }\end{array}$ & $\begin{array}{c}\text { Percentage of } \\
\text { germination }\end{array}$ & $\begin{array}{c}\text { Beta- } \\
\text { carotene }\end{array}$ \\
\hline \multicolumn{2}{l}{ Interaction Gibberellic Acid and Salt Stress } \\
A0C0 & $2634.333 \mathrm{a}$ & $1348.333 \mathrm{a}$ & $100,000 \mathrm{a}$ & $3.491 \mathrm{~b}$ \\
$\mathrm{~A} 0 \mathrm{C} 1$ & - & - & $88,890 \mathrm{~b}$ & - \\
$\mathrm{A} 1 \mathrm{C} 0$ & $2350.667 \mathrm{~b}$ & $1265.333 \mathrm{~b}$ & $100,000 \mathrm{a}$ & $3.547 \mathrm{a}$ \\
$\mathrm{A} 1 \mathrm{C} 1$ & $1159.667 \mathrm{c}$ & $824.000 \mathrm{c}$ & $100,000 \mathrm{a}$ & - \\
\hline
\end{tabular}

Means values in a column and row followed by unlike letter (s) are significantly different at 5\% level using DMRT (Duncan Multiple Range Test).

Attempts to improve yield under stress conditions by plant improvement have been mostly unsuccessful, primarily due to the multigenic origin of the adaptive responses. Therefore, a well-focused approach combining the molecular, protectant such as osmoprotectants (proline, glycine betaine, trehalose, etc.), plant hormone (gibberellic acids, jasmonic acids, brassinosteroids, salicylic acid, etc.) have been found useful in mitigating the salt- physiological, biochemical and metabolic aspects of salt tolerance is essential to develop salt-tolerant crop varieties. Exploring suitable ameliorants or stress alleviant is one of the tasks of plant biologists. In recent decades exogenous induced damage in plant (Ahmad et al., 2011; Azzedine et al., 2011).

Salinity not only affects leaf morphology and transpiration rate but also 
leads to a reduction of total chlorophyll content as the salt concentration increases.

\section{CONCLUSION}

Gibberellic acid (5 mg L-1) and salinity (4-5 dsm-1) on growth and production of roselle help maintain germination success although chlorophyll $\mathrm{a}$ and $\mathrm{b}$ decreased and was not formed flowers (generative phase) to be harvested.

\section{REFERENCES}

Ahmad, P dan S. Umar. (2011). Oxidative stress: role of antioxidants in plants. Studium Press, New Delhi.

Ali. H.M., M.H. Siddiqui., M.O. Basalah., M.H. Al-Whaibi., A.M. Sakran and A. Al-Amri. (2011). Effects ofgibberellic acid on growth and photosynthetic pigments of Hibiscus sabdariffa L. under saltstress. Afr J Biotechnol 11:800-804.

Azzedine, F., H. Gherroucha and M. Baka. (2011). Improvement of salt tolerance in durum wheat by ascorbic acid application. J Stress Physiol Biochem 7:27-37.

Campbell, N.A., J.B. Reece, and L. G. Mitchell. 2005. Biologi. Edisi ke5.Terj. Dari: Biology. 5th ed. oleh Manulu, W. Jakarta: Erlangga.

Maharani A, Suwirmen and ZA Noli. (2018). Pengaruh Konsentrasi Giberelin $\left(\mathrm{GA}_{3}\right)$ terhadap Pertumbuhan Kailan (Brassica oleracea L. Var alboglabra) pada Berbagai Media Tanam dengan Hidroponik Wick System. Jurnal Biologi Universitas Andalas (J. Bio. UA.). 6(2) hal: 63-70 (ISSN : 23032162)

Moosavi, S.G., M.J. Saghatoleslami., H. Javadi., S.M. Moosavi., Z. Jouyban., E. Ansarina and M. Nasiri. (2013). Effect of Salt Stress on Germination and Early
Seedling Growth of Roselle (Hibiscus sabdariffa). Global Journal of Medicine Plant Research, 1(1):124127,2013.

Nasifa IH and P Husni. (2018). Potensi Antioksidan Dalam Kelopak Bunga Rosella (Hibiscus sabdariffa L.) Sebagai Anti-Aging. Jurnal Farmaka Suplemen. Vol. 16, No. 2

Novita, A., A.R. Cemda and H. Julia . (2017). Effects of Plant Hormones Interaction Under Salt Stress on Growth of Roselle (Hibiscus Sabdarifa L.). ICoSAaNRM 2017. ISBN 978-602-6997-70-8. Hal: 88-95.

Yasmin. 2014. Pengaruh Perbedaan Waktu Aplikasi Dan Konsentrasi Giberelin (Ga3) Terhadap Pertumbuhan Dan Hasil Tanaman Cabai Besar (Capsicum annuum L.) Jurnal Produksi Tanaman. Volume 2, Nomor 5, Juli 2014, hlm. 395-403 